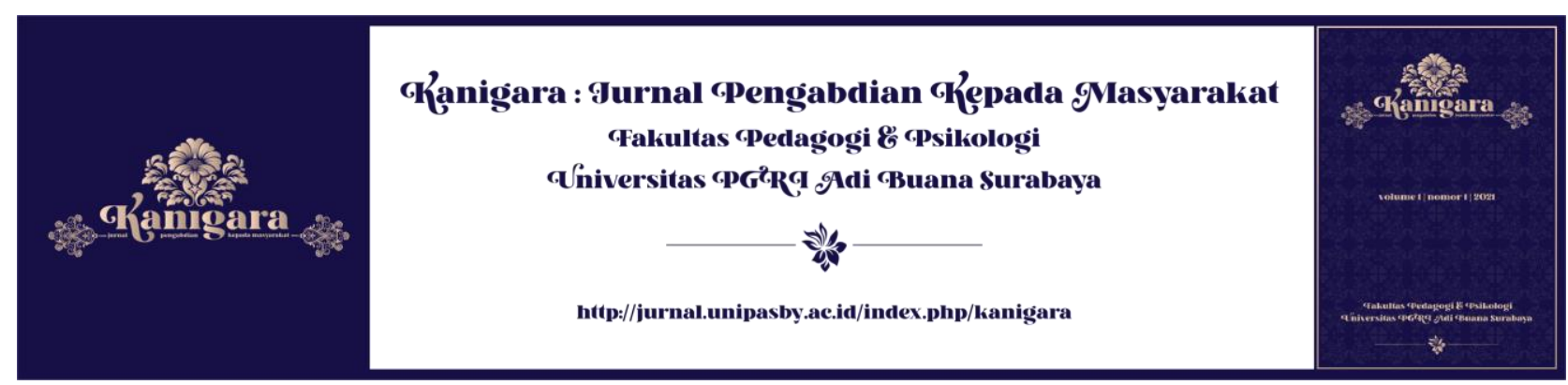

\title{
PELATIHAN PENYUSUNAN PENELITIAN TINDAKAN KELAS BAGI GURU UPT SMP N 10 GRESIK
}

\author{
Tri Indrayanti ${ }^{1}$, Agung Pramujiono ${ }^{2}$, Sri Budi Astuti ${ }^{3}$, Indayani ${ }^{4}$, Nur Rohma $^{5}$, \\ 1,2,3,4,5 Prodi Pendidikan Bahasa Indonesia, Universitas PGRI Adi Buana Surabaya \\ *Email: indrayanti.trie18@unipasby.ac.id
}

\begin{tabular}{l}
\hline Informasi Artikel \\
\hline Kata kunci: \\
Penulisan, PTK, \\
guru SMP \\
\\
Diterima: 12-01-2021 \\
Disetujui: 20-01-2021 \\
Dipubikasikan: 25-01- \\
2021
\end{tabular}

2021

\begin{abstract}
Abstrak
Penulisan karya tulis ilmiah menjadi persoalan tersendiri dalam dunia pendidikan baik di jenjang pendidikan dasar, pendidikan menengah, maupun pendidikan tinggi. Penelitian tindakan kelas (PTK) merupakan salah satu bentuk karya ilmiah yang harus ditulis oleh guru. Masalah yang muncul dalam penulisan PTK diantaranya yaitu merefleksikan lemahnya berpikir logis dan belum mampu berpikir kitis. Karakteristik masalah intelektual tersebut diantaranya tulisan ilmiah yang tidak merefleksikan proses kajian kritis terhadap teori atau fenomena yang muncul dalam dinamika masyarakat, teknis dan cara penulisan ilmiah dalam per bab menggambarkan modus display theory tanpa dilandasi struktur berpikir logis (logical frame work) yang jelas. Fenomena seperti ini memang banyak ditemukan dalam penulisan KTI dalam hal ini PTK dan ujungnya mengarah pada tindak plagiarisme. Solusi yang ditawarkan untuk mengatasi permasalahan tersebut yaitu mengadakan pelatihan secara intensif bagi guru UPT SMP N 10 Gresik. Pelatihan dan pendampingan secara intensif diharapkan mampu meningkatkan kualitas guru dalam menulis PTK. Keefektifan pelatihan bisa dilihat dari hasil penulisan PTK oleh guru dan hasil angket yang diisi oleh peserta pengabdian kepada masyarakat.
\end{abstract}

\footnotetext{
Abstact

Writing scientific papers has become a particular problem in education, at the primary, secondary, and higher education levels. Classroom Action Research (CAR) is a form of scientific work written by the teacher. The problems that arise in the writing of CAR include reflecting the weakness of logical thinking and not being able to think critically. The characteristics of these intellectual problems include scientific writing that does not reflect the critical review process of theories or phenomena that arise in society's dynamics, technical and scientific writing in each chapter describes the display theory mode without an actual logical framework. This phenomenon is often found in the writing of scientific papers; in this case, CAR and ultimately leads to plagiarism. The solution offered to overcome these problems is to conduct intensive training for teachers of UPT SMP N 10 Gresik. Intensive training and mentoring are expected to improve the quality of teachers in writing CAR. The training's effectiveness can be seen from the results of the writing of the CAR by the teacher and the results of the questionnaire filled out by community service participants.
} 


\section{PENDAHULUAN}

Di era teknologi revolusi industri 4.0 sebagian besar perusahaan menggunakan teknologi untuk menjual produk secara online. Hal ini diperlukan untuk meningkatkan penjualan dengan cara cepat dan menghasilkan laba yang banyak. Dalam dunia pendidikan, teknologi dalam pembelajaran juga memanfaatkan fasilitas internet sebagai salah satu adanya perubahan revolusi industri yang tidak dapat dihindari. Berkaitan dengan penggunaan teknologi, agar lulusan sekolah bisa kompetitif kurikulum perlu orientasi baru, sebab dengan adanya era revolusi industry 4.0 tidak hanya dibutuhkan pemahanan literasi sebagai modal dasar untuk berkiprah di masyarakat, namun kiprah tersebut harus diikuti dengan kemampuan menggunakan informasi (big data) di dunia digital, memahami cara kerja mesin, dan aplikasi teknologi.

Berkaitan dengan hal tersebut, dalam proses pembelajaran pendidik diharapkan melakukan perubahan-perubahan berkaitan dengan model pembelajaran yang digunakan. Di antaranya model pembelajaran berbasis teks. Model pembelajaran ini menggunakan segala teks yang ada di sekitar peserta didik, di antaranya teks elektronik maupun teks nonelektronik yang dapat diakses di mana saja (buku, referensi, internet, wa melalui hp, Koran, majalah, dan lain-lain). Di sinilah pendidik dan peserta didik harus dapat bekerja sama.

Selain itu, kemampuan pendidik dalam mengelola dan mengevaluasi selama proses pembelajaran sangat bermanfaat untuk refleksi diri. Bagi seorang pendidik, refleksi diri harus selalu dilakukan setelah selesai pembelajaran guna perbaikan proses untuk mencapai tujuan berikutnya. Refleksi diri dapat dilakukan melalui penelitian tindakan kelas, yaitu penelitian yang dilakukan ketika pembelajaran tidak mencapai hasil yang diharapkan. Hal ini penting dilakukan mengingat pembelajaran dengan menggunakan teknologi kekinian tidak semua pendidik melakukannya, bahkan sebagian besar pendidik masih menggunakan model pembelajaran konvensional, kemampuan pendidik dalam meneliti masih rendah, dan kemampuan menyusul karya ilmiah masih rendah.

Penulisan KTI menjadi persoalan tersendiri dalam dunia pendidikan baik di jenjang pendidikan dasar, pendidikan menengah, maupun pendidikan tinggi. Syaefullah (2015:5-6) menyatakan bahwa masalah umum dalam penulisan KTI adalah masalah intelektual yaitu meluasnya penggunaan modus berpikir imitatif. Masalah ini merefleksikan lemahnya berpikir logis. Karakteristik masalah intelektual tersebut yaitu (1) tulisan ilmiah yang tidak merefleksikan proses kajian kritis terhadap teori atau fenomena yang muncul dalam dinamika masyarakat dan (2) teknis dan cara penulisan ilmiah dalam bab 1 dan bab 2 menggambarkan modus display theory tanpa dilandasi struktur berpikir logis (logical frame work) yang jelas. Fenomena seperti ini memang banyak ditemukan dalam penulisan KTI dan ujungnya mengarah pada tindak plagiarisme.

Permasalahan dalam penulisan KTI juga dialami oleh para guru di UPT SMP N 10 Gresik. 
Berdasarkan hasil diskusi dengan Kepala Sekolah UPT SMP N 10 Gresik, diketahui berbagai permasalahan yang dihadapi oleh guru-guru, khususnya yang berkaitan dengan penulisan artikel hasil PTK Karya Ilmiah. Hal ini terbukti dengan tingginya tingkat kegagalan ketika mereka mengajukan kenaikan angka kredit (PAK) ke golongan IV dan ketika mengikuti lomba guru prestasi. Penyebab kegagalan tersebut adalah pada penulisan karya ilmiah, khususnya dalam penulisan artikel PTK untuk publikasi ilmiah.

\section{METODE}

Pelaksanaan kegiatan pengabdian kepada masyarakat ini dilakukan oleh tim dosen dan mahasiswa jurusan Pendidikan Bahasa Indonesia, FISH Universitas PGRI Adi Buana Surabaya pada tanggal 24 Agustus 2020 secara virtual/daring. Hal ini dilaksanakan karena kondisi masih pandemi dan tidak memungkinkan untuk tatap muka secara langsubng. Metode yang digunakan adalah dengan melakukan sosialisasi, pelatihan, dan pendampingan bagi guru UPT SMP N 10 Gresik Jawa Timur. Tahapan pelaksanaan kegiatan pengabdian kepada masyarakat dapat dilihat pada Gambar 1.

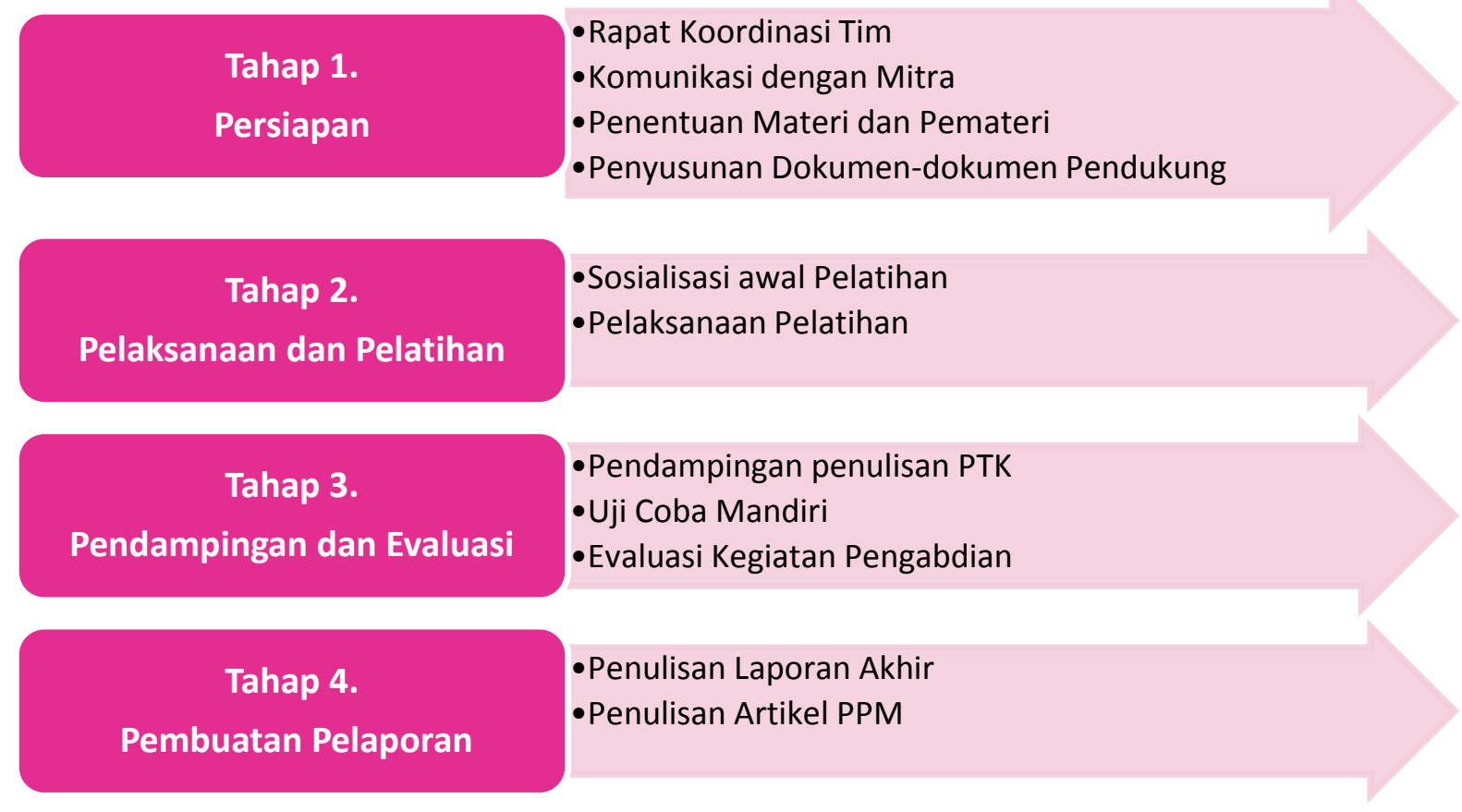

Gambar 1. Tahapan Pelaksanaan Kegiatan Pengabdian kepada Masyarakat

Pada tahap 1 (tahap persiapan) ini tim panitia PPM Prodi PBI berkoordinasi untuk melakukan observasi awal dan berkomunikasi dengan sekolah mitra (Kepala Sekolah UPT SMP N 10 Gresik) mengenai kesulitan yang dihadapi guru saat menyusun PTK. Kemudian tim panitia melaksanakan rakor untuk menentukan materi, pemateri, dan dokumendokumen pendukung seperti surat ijin, surat permohonan, surat tugas, dan presensi, bedrop, 
sertifikat. Pada tahap 2 (pelaksanaan dan pelatihan) ini tim melakukan sosialisasi awal mengenai kegiatan pelatihan dan melaksanakan kegiatan pelatihan yang telah disepakati bersama. Salah satu kesepakatan yang diambil yaitu kegiatan dilaksanakan secara daring/virtual karena kondisi dan situasi kurang mendukung untuk tatap mukla secara langsung. Pada tahap 3 (pendampingan dan evaluasi) ini tim pemateri melakukan kegiatan pendampingan bagi guru dalam pembuatan Penelitian Tindakan Kelas bagi Guru Guru sesuai dengan mata pelajaran yang diampu sehingga guru lebih mudah mengaplikasikannya apa yang akan disampaikan proposal dan laporan PTK. Setelah pendampingan selesai, tim PPM mengadakan evaluasi dengan memberikan angket keterlaksanaan program PPM Prodi PBI dan mereviu hasil penulisan PTK guru-guru UPT SMP N 10 Gresik. Pada tahap 4 (tahap pembuatan pelaporan), tim PPM berkoordinasi dengan sub tema masing-masing untuk menyusun laporan akhir kegiatan PPM dan melakukan persiapan publikasi ilmiah (artikel pengabdian).

Pada tahap persiapan, selain penyusunan dan koordinasi serta komunikasi dengan mitra, kegiatan yang dilakukan lainnya adalah membuat materi. Materi pelatihan yang disampaikan saat kegiatan pengabdian kepada masyarakat disajikan dalam Tabel 1 di bawah ini.

Tabel 1. Materi Pelatihan

\begin{tabular}{|c|l|}
\hline PROGRAM & \multicolumn{1}{|c|}{ MATERI PELATIHAN } \\
\hline Sosialisasi & $\begin{array}{l}\text { Sosialisasi pentingnya penulisan PTK bagi guru yang } \\
\text { berkaitan dengan kualitas pembelajaran dan profesionalisme } \\
\text { guru } \\
\text { - } \begin{array}{l}\text { Penyamaan persepsi standard an sistematika PTK dan } \\
\text { memberikan konsep bahwa menulis PTK itu mudah. }\end{array}\end{array}$ \\
\hline Pelatihan & $\begin{array}{l}\text { Berpikir kritis dan analitis dalam menulis KTI } \\
\text { Penguasaan Bahasa Indonesia ragam ilmiah }\end{array}$ \\
& $\begin{array}{l}\text { Sistematika dan komponen-komponen penulisan KTI } \\
\text { khususnya PTK }\end{array}$ \\
& $\begin{array}{l}\text { Pemilihan diksi, pengalimatan, pengohesivan, sitasi, dan } \\
\text { penulisan referensi, serta pegeditan yang baik dalam } \\
\text { penulisan PTK }\end{array}$ \\
\hline Pendampingan & $\begin{array}{l}\text { Pendampingan kepada guru UPT SMP N 10 Gresik dalam } \\
\text { proses penulisan PTK yang disesuaikan dengan materi yang } \\
\text { dijarkan di kelas }\end{array}$ \\
\hline Evaluasi & \begin{tabular}{l} 
Evaluasi kegiatan dan refleksi tim panitia PPM dan guru \\
\hline
\end{tabular} \\
\hline
\end{tabular}




\section{HASIL DAN PEMBAHASAN}

Kegiatan pengabdian pada masyarakat ini bertujuan untuk meningkatkan penulisan penelitian tindakan kelas guru UPT SMP N 10 Gresik sebagai upaya mengatasi permasalahan yang ditemukan di lapangan yaitu belum maksimalnya guru dalam penulis PTK, adanya ketidakpercayaan guru dalam menulis PTK, dan masih rendahnya pengetahuan guru dalam penguasaan teknik dan sistematika penulisan PTK, serta cara publikasi hasil penulisan PTK. PTK merupakan salah satu kebutuhan untuk dalam meningkatkan kualitas pembelajaran. Selain itu, PTK juga memiliki point yang cukup tinggi untuk meningkatkan jabatan fungsional guru.

Solusi permasalahan yang ditawarkan dalam mengatasi permasalahan tersebut di atas yakni dengan memberikan pelatihan dan pendampingan intensif dalam penyusunan PTK dengan memanfaatkan Ms word bagi guru UPT SMP N 10 Gresik. Tahapan pelatihan diawali dengan mengadakan sosialisasi akan pentingnya penulisan PTK bagi guru dalam mengukur kualitas pembelajaran di kelas, kemudian melakukan penyamaan persepsi penulisan PTK sesuai dengan mapel guru, dan yang terakhir adalah pendampingan penulisan PTK secara intensif hingga pelaporan dan publikasi hasil penulisan PTK. Kegiatan sosialisasi yang dilaksanakan adalah sosialisasi tentang pentingnya penulisan PTK bagi guru. Pentingnya penulisan PTK tersebut sebagai produk nyata untuk melihat kualitas dan kompetensi guru dalam melakukan proses pembelajaran di kelas. Selain itu, sebagai tagihan untuk meningkatkan jabatan fungsional, PTK juga menjadi salah satu prasyaratnya. Setelah kegiatan sosialisasi, kegiatan berikutnya adalah pemberikan materi cara berpikir kritis dan analitis dalam menulis KTI, hal ini penting diberikan karena masih banyak guru yang hanya berpikir teoretis, bukan praktis. Sehingga masalah apa yang dihadapi guru saat mengajar di kelas merupakan permasalahan yang bisa ditulis dalam PTK. Selain itu, materi tentang penguasaan Bahasa Indonesia ragam ilmiah, materi ini juga penting karena beberapa guru terkadang masih menggunakan bahasa keseharian dalam menulis KTI (PTK), selanjutnya yakni banyak guru yang masih belum menguasai betul tentang sistematika dan komponen-komponen penulisan KTI dalam penulisan PTK, dan yang terakhir guru juga masih kesulitan dalam pemilihan diksi, pengalimatan, pengohesivan, sitasi, dan penulisan referensi, serta pegeditan yang baik dalam penulisan PTK secara umum. Pada tahap pelatihan ini, guru terlihat sangat antusias dalam membuat menyimak materi tentang PTK. Hal ini ditunjukkan dengan hampir semua guru yang mengikuti pelatihan mengumpulkan proaktif dalam sesi tanya jawab dan menyampaikan kesulitan-kesulitan saat dihadapi dalam menulis PTK. 


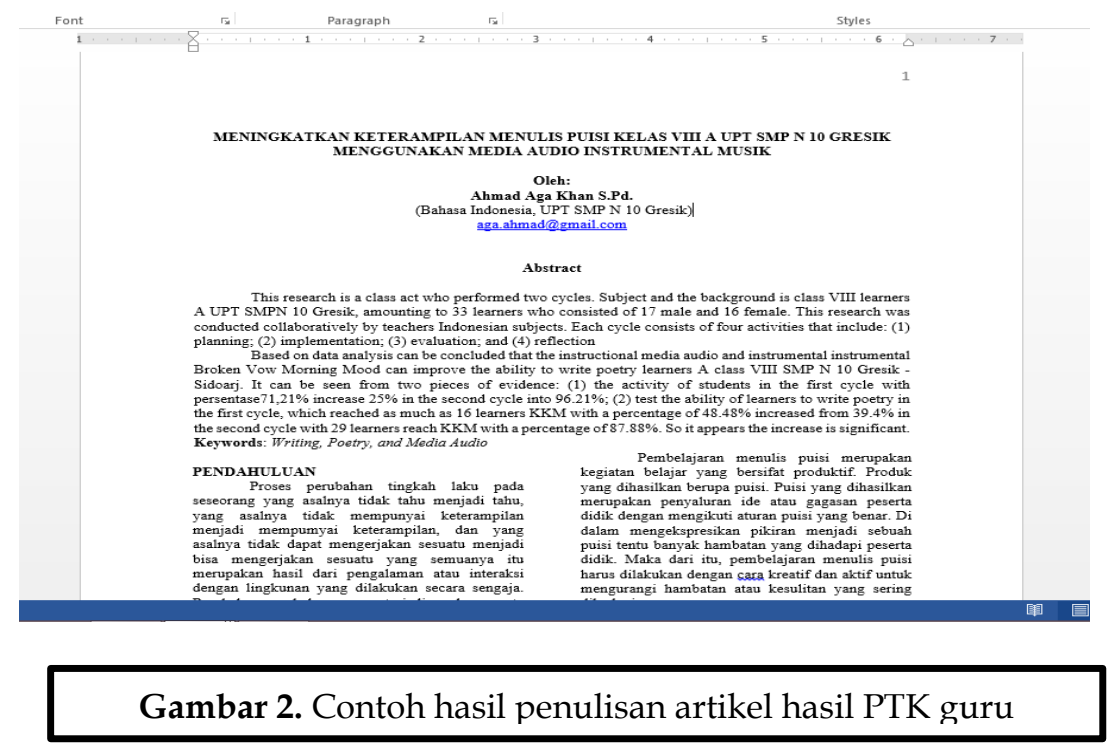

Gambar 2 di atas adalah salah satu contoh karya berupa artikel hasil PTK yang ditulis oleh guru di UPT SMP N 10 Gresik. Artikel tersebut berjudul "Meningkatkan Keterampilan Menulis Puisi Kelas VIII A UPT Smp N 10 Gresik Menggunakan Media Audio Instrumental Musik". Secara sistematis dan konten, judul yang dibuat sudah sesuai dengan sistematika yang ada. Judul PTK dan artikel tersebut didasarkan pada masalah yang dihadapi oleh siswa khususnya mapel Bahasa Indonesia materi menulis puisi. Sehingga masalah yang dihadapi siswa tersebut, guru mempersiapkan media inovatif yang akan dijadikan sebagai obat untuk memudahkan siswa menulis puisi yaitu menggunakan media audio instrumental musik.

Berikut akan dipaparkan contoh hasil analisis penelitian PTK yang sudah dilakukan oleh guru di UPT SMP N 10 Gresik. (gambar 3).

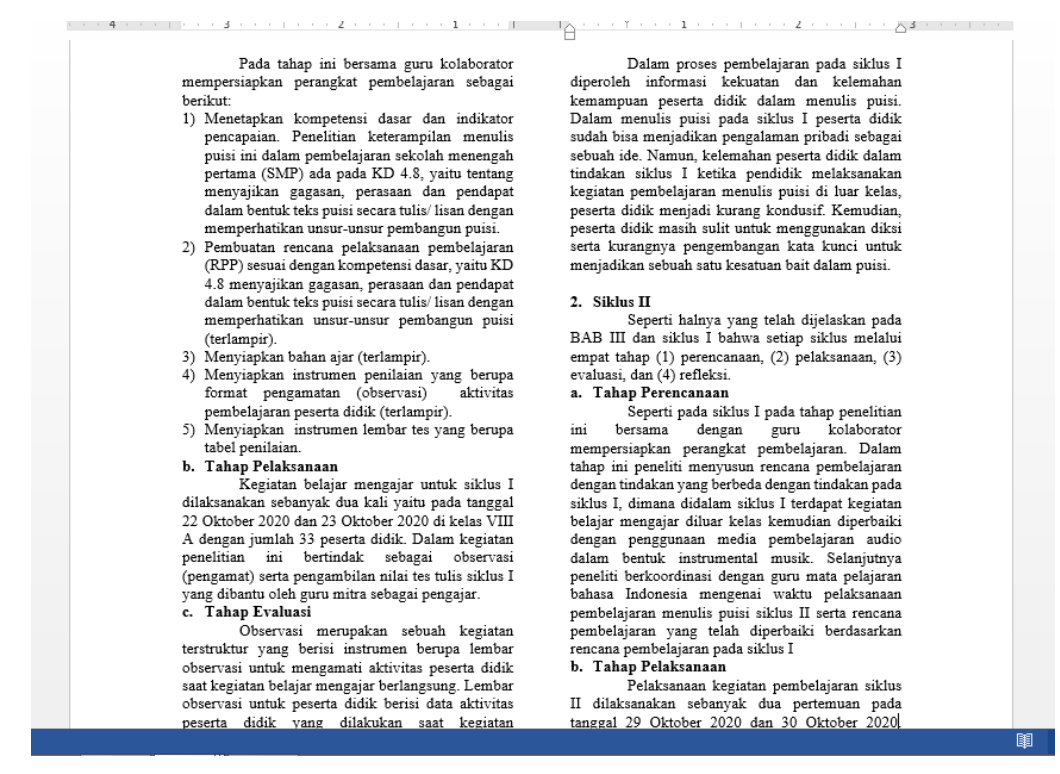

Gambar 3. Contoh hasil analisispenulisan artikel hasil PTK guru 
Berdasarkan analisis data (gambar 3) di atas bisa disimpulkan bahwa media pembelajaran audio dalam bentuk instrumental musik Broken Vow dan Morning Mood dapat meningkatkan kemampuan menulis puisi peserta didik kelas VIII A UPT SMP N 10 Gresik dibandingkan dengan kegiatan pembelajaran diluar kelas. Hal tersebut dapat dilihat pada dua bukti yang meningkat dari proses belajar peserta didik yaitu (1) aktivitas peserta didik pada siklus I dengan persentase $71,21 \%$, meningkat $25 \%$ pada siklus II menjadi $96,21 \%$; (2) tes kemampuan menulis puisi peserta didik siklus I yang mencapai KKM sebanayk 16 peserta didik dengan persentase 48,48\%, meningkat $39,4 \%$ pada siklus II dengan ketercapaian KKM sebanyak 29 peserta didik dengan persentase $87,88 \%$. Sehingga tampak adanya kenaikan yang signifikan.

Dua gambar di atas (1) dan (2) adalah salah satu contoh hasil penulisan PTK yang menunjukkan bahwa proses pelatihan dan pendampingan memiliki pengaruh yang sangat luar biasa untuk guru di UPT SMPN 10 Gresik. Kegiatan pendampingan dan lanjutan akan tetap dilaksanakan untuk meningkatkan guru dalam menulis PTK ke depannya.

Setelah rangkaian kegiatan pengabdian pada masyarakat yang dilaksanakan secara daring selesai, guru-guru UPT SMP N 10 Gresik kemudian diminta untuk mengisi kuesioner melalui online (google sheet) mengenai keterlaksanaan kegiatan pengabdian. Evaluasi kegiatan pengabdian meliputi kesesuaian materi yang disampaikan dengan tujuan kegiatan, kejelasan penyampaian materi, kecukupan waktu yang digunakan, kebermanfaatan materi yang diberikan, materi yang mudah dimengerti, dan keberlanjutan peserta menerapkan materi dalam pembelajaran. Dari hasil kuesioner, diperoleh rata-rata nilai total sebesar 3,78 sehingga dapat dikatakan bahwa kegiatan pengabdian kepada masyarakat ini terlaksana dengan maksimal dan sangat baik.

\section{KESIMPULAN}

Sebagian besar guru di UPT SMP N 10 Gresik belum mampu menulis penelitian tindakan kelas (PTK). Kesulitan muncul dari banyak faktor. Setelah mendapat pelatihan, sebagian besar guru mengatakan bahwa mereka mendapat tambahan pengetahuan tentang apa itu konsep menulis PTK dan fungsinya dalam meningkatkan kulitas guru. Guru juga mendapat tambahan keterampilan dengan langsung melalui pendampingan secara intensif dalam memulai menulis PTK, menemukan masalah di kelas, dan menyusun PTK secra rinci yang disesuaikan dengan mat pelajaran yang diampu oleh masing-masing guru.

Secara umum kegiatan pengabdian pada masyarakat oleh Prodi PBI berjalan dengan lancar dan tertib. Guru di UPT SMP N 10 Gresik tampak antusias dalam menyimak materi yang diberikan dengan seksama. Antuasime peserta pelatihan ditunjukkan dengan banyaknya peserta yang mengajukan pertanyaan seputar materi yang diberikan saat sesi 
Tanya jawab, dan keseriusan peserta saat mulai menulis PTK (menemukan masalah di kelas dan lain sebainya). Kegiatan pelatihan dinilai efektif karena melihat hasil kuesioner, tingkat keterlaksanaan kegiatan pengabdian cukup tinggi dan peserta mengharapkan kegiatan lanjutan dalam menulis PTK. Selain itu, berdasarkan hasil kegiatan, dapat disimpulkan bahwa kegiatan pengabdian ini telah mencapai tujuan yang diharapkan yaitu lebih dari 90\% guru bisa menulis PTK dengan baik sekaligus menulis artikel hasil PTK dengan bagus.

\section{UCAPAN TERIMA KASIH}

Penulis mengucapkan terima kasih kepada Universitas Universitas PGRI Adi Buana Surabaya melalui Lembaga Penelitian, Pengembangan, dan Pengabdian kepada Masyarakat (LP3M) yang telah mendanai program ini dan UPT SMP N 10 Gresik sebagai mitra yang telah mendukung terlaksanakanya program PPM Prodi PBI ini. Program lanjutan akan tetap dilaksanakan.

\section{DAFTAR PUSTAKA}

Arifin, E.Z. dan Tasai, S.A. 2006. Cermat Berbahasa Indonesia untuk Perguruan Tinggi. Jakarta: Penerbit Akademika Pressindo.

Dalman. 2014. Menulis Karya Ilmiah. Jakarta: PT RajaGrafindo Persada.

Hiryanto. 2014. “Optimalisasi Penerapan Konsep Andragogi dalam Diklat Aparatur Pemerintah sebagai Upaya Peningkatan Mutu Lulusan di Badan Diklat Propinsi Daerah Istimewa Yogyakarta" dalam http: staff.uny.ac.id/ diunduh 20 Mei 2016 Pkl 16.00.

http://nasional.kompas.com/read/2010/03/19/04191796/Lemah.Kemampuan.Guru.Menulis.Karya.

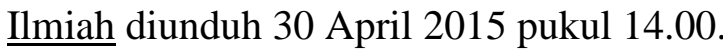

http://www.republika.co.id/berita/pendidikan/berita/10/05/24/116782-karya-ilmiah-jadi-kendala-

kenaikan-pangkat-para-guru diunduh 30 April 2015 pukul 13.50.

Kalidjernih, F. K. 2010. Penulisan Akademik Esai, Makalah, Artikel Jurnal Ilmiah, Skripsi, Tesis,

Disertasi. Bandung: Widya Aksara Press.

Kuntarto, N. M. 2007. Cermat dalam Berbahasa Teliti dalam Berpikir. Jakarta: Penerbit Mitra Wacana Media.

Kuntarto, N. M. dan Putranto,H. 2015. 99 Cara Mudah menulis Karya Ilmiah. Yogyakarta: PT Indopublika.

Malik, H. 2011. "Teori Belajar Andragogi dan Penerapannya " dalam http://www.kompasiana.com/ diunduh 20 Mei 2016 Pkl 16.00.

Sudjana, H.D. 2005. Strategi Pembelajaran. Bandung: Falah Production.

Suyanto dan Jihad, A. 2013. Menjadi Guru Profesional Strategi Meningkatkan Kualifikasi dan Kualitas Guru di Era Global. Jakarta: Penerbit Erlangga. 
Syaefullah, A. 2015. Prinsip Dasar Penyusunan dan Penulisan Karya Tulis Ilmiah (The Fundamental of Scientific Writing). Jakarta: Grasindo.

Yuliana, L. Tanpa tahun. "Format Penyusunan Karya Ilmiah" dalam http://staff.uny.ac.id/ diunduh 30 April 2015 pukul 14.15. 